\title{
0 desporto e histórias de vida. Proposta de um novo itinerário a partir de uma visão personalista
}

\author{
Rui Proença Garcia ${ }^{1}$ \\ Paula Portugal ${ }^{1,2}$
}

https://doi.org/10.5628/rpcd.09.01.90
${ }^{1}$ Centro de Investigação, Formação,

Inovação e Intervenção em Desporto $\left(C^{2} F^{2} D\right)$

Faculdade de Desporto

Universidade do Porto

Portugal

${ }^{2}$ Escola Superior de Tecnologia da Saúde do Porto

Portugal

\section{RESUMO}

As histórias de vida são cada vez mais frequentes nas ciências do desporto. Normalmente abordam a vida passada de ídolos do desporto, sendo uma tentativa de compreender o presente através da vida passada. Porém, uma vida não é apenas formada pelo tempo passado e presente, mas também pelo futuro, pelo que os autores propõem um novo itinerário para o estabelecimento das histórias de vida. Baseados numa perspectiva personalista, os autores fundamentam um percurso de vida onde o futuro surge com um poder explicativo sobre o tempo presente, adicionando esta perspectiva às já descritivas visões diacrónica e sincrónica existentes. Concluem ainda que mais do que uma história de vida há histórias de vidas, sendo cada história uma narrativa de vários sujeitos, naquilo que denominam de intersubjectividade.

Palavras-chave: desporto, histórias de vida, personalismo, tempo
ABSTRACT

Sport and life stories.

A proposal for a new itinerary based on a self concept

Life stories are becoming more frequent as far as sciences of sport are concerned. They usually approach the sportive idols' past life in order to understand the present. But life is not only about the past and the present; there is a need to consider the future. Therefore, authors propose a new kind of itinerary to gather and build life stories. Based on a kind of self perspective, authors work in scenery where the future rises within its explanatory power over the present time, adding this new idea to the well known diachronic and synchronic visions. The inevitable conclusion is that beyond a life story there are innumerous life stories /histories, several narratives with several subjects together in a whole of inter subjectivity.

Key-words: sport, life stories, personalism, time 


\section{INTRODUÇÃO}

Ao longo dos tempos, sem excepção deste que transcorre, surgiram regularmente personalidades que marcaram e fascinaram o mundo. Foram e são pessoas ímpares, excepcionais, cujas histórias dos feitos estão perpetuadas em livros e, não raras vezes, em mitos. Um pouco por todo o lado, em grandes e pequenas bibliotecas, repousa um vasto número de biografias de estadistas, de homens com sucesso nos negócios e de grandes vultos da cultura, da ciência, da sociedade castrense e aventureiros de antanho que pelos seus feitos ocuparam o seu lugar, por direito próprio, no panteão da humanidade. Rostos de épocas passadas que ainda hoje são referências para a humanidade. São histórias exemplares, algumas mitificadas, que elevam essas pessoas ao superior patamar da condição humana, adentrando na dimensão transcendental, ultrapassando o imperativo da finitude humana.

Também no panorama do desporto as histórias de vida estão a ressurgir. Com efeito, nos últimos anos tem aparecido no nosso país um elevado número de livros que versam a vida de determinadas personalidades, em especial daquelas ligadas ao mundo do futebol. São biografias, muitas vezes com características autobiográficas, embora escritas com o apoio de terceiros, que mostram os caminhos trilhados desde a infância até à ascensão ao estrelato de figuras que se tornaram públicas por via do desporto.

Essas biografias, que fazem as delícias das "publicações cor-de-rosa", conseguem grandes tiragens, tendo até capacidade de influenciar o poder judicial ao revelarem pretensos factos ocorridos em torno do futebol. Sem dúvida que são edições interessantes para a sociedade em geral, mas com uma reduzida importância para as ciências do desporto. Os factos relatados poderão ser atractivos para algum tipo específico de público, embora sem qualquer outro valor para além daquele inerente ao consumo imediato. A sociedade de consumo e da frivolidade também se mostra através deste tipo de literatura. No entanto, este género de publicações tem a particularidade de mostrar que o desporto, como aliás qualquer outra actividade humana, é realizado por pessoas, com os seus dramas e angústias, com sonhos e anseios, e que os seus trajectos de vida comprovam que só com grande esforço e dedicação se consegue alcançar o êxito. Mesmo sem grande interesse cientí- fico, as biografias disponíveis no mercado livreiro apontam claramente para uma visão ética da vida, onde o melhor só conseguiu alcançar a excelência por via do trabalho árduo, concretizando a ideia simbólica que só no dicionário é que as palavras êxito e sucesso vêm antes da palavra trabalho.

Mas as histórias de vida, entendidas enquanto processo de investigação sistemática, metódica, rigorosa e referendada pelos cânones da ciência, têm já uma razoável expressão no areópago das ciências do desporto, como se pode verificar pela produção de dissertações académicas na Faculdade de Desporto da Universidade do Porto, que se tem destacado a nível nacional pelo incremento destes estudos. Sem exaustão, podemos lembrar que nesta instituição já se apresentaram dissertações sobre o que é ser bom professor a partir de sete histórias de vida [Antonino Pereira ${ }^{(23)}$ ], sobre o percurso de Mário Zagallo, um ícone do futebol mundial [Jayme Valente ${ }^{(40)}$ ] e um dramático testemunho sobre o (não) desenvolvimento motor de uma criança através da visão de seus pais [Fátima Santos(35)]. Neste momento estão em curso estudos que pretendem estabelecer a história de Nuno Delgado, talvez o mais importante judoca português de todos os tempos, buscando elementos para a compreensão do seu êxito desportivo (José Mário Cachada), do inesquecível Mané Garrincha (Humberto Rêdes) e, numa óptica um pouco diferente, de idosos de duas comunidades diferenciadas, urbana e rural, acerca das suas visões pessoais sobre a relação da actividade física desportiva com o conceito de vida (Paula Portugal). Este último trabalho possui a particularidade de não se deter em visões elitistas da vida mas investigar o homem comum de regiões culturalmente distintas.

Ainda em língua portuguesa, com a sonoridade tropical, é justo realçar o trabalho desenvolvido por Kátia Rubio(32), da Universidade de São Paulo, que há bastante tempo busca através das histórias de vida compreender intimamente os desportistas do seu país.

Há muito que defendemos a posição de que mais importante do que discutir abstractamente desporto, interessa enfatizar o seu praticante, invariavelmente um ser humano, pelo que as histórias de vida dãonos uma preciosa ajuda para a compreensão de um dos maiores fenómenos culturais do mundo actual, exactamente o desporto. 
Contudo, talvez fruto da sucessão de trabalhos já realizados com a nossa participação, não nos sentimos confortáveis com algumas tendências seguidas pelas histórias de vida, bastante lineares e assentes numa perspectiva diacrónica de vida, pelo que o nosso propósito é reflectir sobre esta denominada metodologia, tentando aprofundar o tema no sentido de lhe conferir uma dimensão humana mais intensa e consentânea com a nossa visão personalista do mundo. Com efeitos, receamos que as histórias de vida se transformem num simples instrumento e não naquilo que de mais profundo poderá possuir na sua designação, a exaltação de uma vida através do conhecimento de toda sua existência, seja ela passada, presente ou projectada para o futuro.

Este trabalho é, então, um convite para uma reflexão trilhada por caminhos próximos ao pensamento antropológico e com breves incursões a autores da filosofia, que nos poderá direccionar para uma nova posição epistemológica, onde a pessoa assuma, de facto, a centralidade da sua narrativa.

\section{HISTÓRIA DE VIDA: DAS RAZÕES DA SUA EXISTÊNCIA}

Por vezes é razoável o recurso a sábios do passado, neste caso do Renascimento, para compreendermos um pouco melhor o alcance de determinados temas actuais.

Giovanni Pico della Mirandola, nobre italiano que viveu entre 1463 e 1496, no seu Discurso sobre a dignidade humana, publicado pela primeira vez em 1486, dizia que "as bestas, no momento em que nascem, trazem consigo do ventre materno (...) tudo aquilo que depois terão"(19: p.57). As histórias de vida de animais não fazem sentido. Os bichos são aquilo porque têm de ser aquilo, enquanto que o homem, ainda nas palavras de Pico della Mirandola, é um "camaleão", não na óptica depreciativa associada a este simpático animal, mas no sentido da sua capacidade de adaptação ao meio envolvente. Uma história de vida poderá ser, então, a narração das metamorfoses que vão ocorrendo no decurso da existência de cada um. Esta evolução da vida possui, contudo, uma característica ímpar que a diferencia profundamente da evolução metamórfica de alguns animais. Enquanto que nestes últimos tudo parece estar inscrito no seu material genético e como tal longe da vontade própria, em nós, humanos, esse desenvolvimento é estranho, pelo menos parcialmente, à referida determinante biológica. Se na vida animal a teleonomia é um finalismo, mas não intencional, no ser humano, a existir um finalismo, será de uma outra ordem. Não nos atrevemos a enunciá-la, mas certamente que não se esgota em aspectos físicos ou biológicos, tangíveis. A este respeito lembra Fernando Savater(36: p.21) que "recebemos com a nossa dotação genética a capacidade inata de levar a cabo comportamentos não inatos", constituindo-se esse facto como um importante salto qualitativo, pelo que a história que queremos contar é a da fracção humana da vida e não referente à sua totalidade enquanto mera evidência do conceito de bíos apontado por Aristóteles(1). Alguma desta vida não será de natureza verdadeiramente humana, mas comum à animalidade e por isso inscrita no património genético que, como é de antever, não terá uma história para contar: simplesmente é. Este modo de pensar o homem também nos é sugerido por Pedro Laín Entralgo(10), médico e filósofo espanhol, quando demonstra que aquilo que somos é fruto de uma tripla herança: do desenvolvimento embriológico, como resultado de um devir histórico e de uma situação social e, por último, desfecho de um processo biográfico. Embora a posição deste autor mantenha intacta uma concepção positivista do ser humano, como sendo fruto de uma evolução biológica e de uma certa convivência social facilmente determináveis, abre-nos um marcante campo de debate, neste caso da possibilidade de compreender o sentido último da história humana, o que nos liberta das determinísticas amarras temporais do passado, projectando-nos para a criação da própria existência.

Igualmente Julían Marías(18: p.25), filósofo espanhol, distingue vida biológica de vida humana, afirmando que só esta última tem a possibilidade de ter uma história em sentido estrito. Na mesma direcção se pronuncia o historiador Marc Bloch, ao distinguir história natural de história humana, dizendo que o homem delibera, a natureza não. Acrescenta ainda que a história humana tornar-se-ia sem sentido se negligenciássemos o facto dos homens terem objectivos, fins e intenções(in 16).

Anthony Giddens ${ }^{(12)}$, ao apresentar as novas regras do método sociológico, assume uma posição análoga àquela enunciada pelos filósofos supracitados, afir- 
mando que a produção e a reprodução da sociedade humana não são biologicamente programadas como acontece nos níveis mais baixos dos animais.

Entre portas, isto é em autores portugueses, também encontramos pensamentos que nos conduzem à percepção da justeza sobre o conceito de vida tal como aqui o temos enunciado. Teixeira de Pascoaes(21: p.270), do alto da sua sageza, estabeleceu os limites da humanidade em relação à animalidade, afirmando que "o destino do homem é exceder a zoologia e o seu próprio ser, isto é, sobre-humanizar-se". Só um poeta para ser tão claro e profundo. Leonardo Coimbra, aqui referido através da pena de Manuel Patrício(2), diferenciava com precisão a "memória biológica", que ainda não é pessoal, da "memória ética", essa sim, característica da pessoa, dado que esta "excede a simples vida".

O homem é artífice de si mesmo. Está dotado do livre-arbítrio, ultrapassando o desígnio criador podendo ser outro, ou, pelo menos, ser diferente daquilo que já foi ou é. Tem razão o autor renascentista atrás referido quando nos esclarece: "Ó suma liberalidade de Deus pai, ó suma e admirável felicidade do homem! ao qual é concedido obter o que deseja, ser aquilo que quer"(19: p.57). O ser humano tem a facilidade - e felicidade - de poder escolher livremente, pelo menos até um certo limite, o decurso da sua vida, tomando opções mais ou menos conscientes, pelo que a sua vida é diferente da dos animais, tornando significativa a sua narração. Robert Atkinson(2), pesquisador norte-americano do campo das ciências sociais, reconhece esta posição, afirmando que as histórias de vida servem para partilhar verdades pessoais que ultrapassam as evidências biológicas, inscrevendo-se no panorama axiológico e por tal num plano irremediavelmente humano.

A vida da criança que nasce ou que é nascida curiosa expressão de Entralgo(10) - comporta a potência de vir a ser profundamente humana ou cultural. É disso que a antropologia trata. É disso que a história de vida deverá tratar, ou seja, deverá ser uma narrativa da concretização da potência aludida. Um nado-morto não possui uma história de vida. Poderá, quanto muito, escrever-se sobre o seu desenvolvimento embrionário ou fetal mas nunca sobre a sua vida humana. Não a teve, e por tal dele não se poderá estabelecer uma autêntica história de vida. Acreditamos que o aristotélico conceito de dýnamis, recuperado pelo nosso tempo por Ilya Prigogine (potência, enquanto aptidão para a mudança), nos ajude a resolver melhor este assunto.

Regressemos à metáfora do camaleão. Para se entender a alteração cromática do camaleão há que conhecer o meio onde e pelo qual se deu tal transformação e, não menos importante, a sensibilidade à cor que cada um possui. Os acontecimentos da vida não poderão ser interpretados sem uma clara referência aos momentos em que foram produzidos ou desencadeados nem, como adiante se discutirá, sem a consciência da diversidade subjectiva motivada pela existência de um narrador e de um narrado.

O homem é um ser que o é num tempo e num espaço, pelo que as suas acções terão que ser julgadas em conformidade com esta premissa. Wittgenstein (43: p.126) alude à imperiosa necessidade de ver cada um no seu tempo e lugar, dizendo: "uma época interpreta falsamente a outra; e uma época mesquinha interpreta erradamente todas as outras à sua própria $\mathrm{e}$ sórdida maneira".

Convenhamos que histórias de vida são interpretações de acções humanas ocorridas e desencadeadas num dado momento e reproduzidas e interpretadas noutras épocas, o que por si só se constitui num problema de elevada complexidade. Diacronia e sincronia são conceitos operatórios que se fazem presentes nas histórias de vida. Ora, mais do que conceitos são dificuldades acrescidas para a correcta compreensão de um estado de vida, dado que essas histórias, pelo menos no campo das ciências do desporto, são referenciadas a um momento preciso. As histórias de vida apelam à memória de cada um, que é um processo que faz intervir não apenas uma simples ordenação de vestígios, mas também uma releitura desses vestígios ${ }^{(15)}$, para mais quando conhecemos o futuro de muitos dos acontecimentos que pela memória reconstruímos. Antero de Quental(28: p.135) apresenta uma perspectiva muito próxima desta ao afirmar que "na ordem dos factos, não se pode construir a priori o que não se conhece já a posteriori", pelo que poderemos estar perante um problema irresolúvel, o de descortinar com precisão aquilo que ocorreu daquilo que posteriormente se diz que ocorreu. 


\section{HISTÓRIAS DE VIDA: UMA METODOLOGIA?}

A palavra metodologia convoca para o seu significado a ideia de caminho ou de condução, isto é um itinerário para se atingir determinado alvo ou objectivo. A selecção de um determinado tipo de metodologia não deve ser uma imposição, uma tendência ou uma moda, mas uma escolha consciente em que o investigador no momento dessa mesma escolha já está a atribuir um sentido e a mostrar-se aos outros. Boaventura Sousa Santos(38: p.48), com razão, afirma que "cada método é uma linguagem e a realidade responde na língua em que é perguntada". Então, optar por uma via - isto é, por uma linguagem - implica renunciar a muitas outras possíveis, algumas das quais tão produtivas como aquela que se pretende seguir. Deste modo, ao decidir-se por este caminho o autor expõe-se expondo a vida de alguém, numa clara confusão (isto é, uma mútua fusão) entre subjectividade e objectividade. Subjectividade, porque o trabalho centra-se no sujeito; objectividade, porque o sujeito da história é em simultâneo objecto de estudo. Assim, poder-se-á aventar a hipótese que a história de vida tem dois sujeitos: quem a elabora e sobre quem é elaborada. A intersubjectividade torna-se presente. À subjectividade de um sujeito, de quem elabora, sobrepõe-se a subjectividade do outro sujeito, sobre quem é realizada a história. São duas vidas que se cruzam, dando corpo a uma história, que é de um sobre o outro, mas de qualquer forma é a história do outro contada por si através de mim [eu]. O eu e o outro fundem-se num só. Há um ir-e-vir entre o autor e o historiado, num movimento permanente, reflectindo-se cada um dos dois na história de um.

Estamos perante um encontro humano, um encontro de sujeitos e, como tal, um encontro espiritual, como nos assevera Henrique Vaz ${ }^{(41)}$.

$\mathrm{O} e u$ do sujeito investigador está presente na apropriação e na apresentação do $e u$ do sujeito investigado, formando um par que só uma dupla hermenêutica poderá desenlaçar. Acresce-se ainda o facto do testemunho oral do sujeito em estudo ser provocado pelo investigador, que muitas vezes conduz o discurso - ou a memória - do entrevistado para factos que previamente seleccionou e que nem sempre seriam recordadas pela pessoa em causa. Há que admitir a possibilidade da causalidade entre factos ser um produto externo ao entrevistado, resultando mais de uma determinada concepção do autor do estudo, que assim tenta "validá-la" com a palavra do outro. O próprio contar da sua vida por parte de alguém já se constitui numa fascinante experiência hermenêutica, uma autohermenêutica nas palavras de Ricardo Vieira ${ }^{(42)}$, que deveremos tomar em devida consideração. William Tierney ${ }^{(39)}$ vai ainda mais longe sobre a autoria das histórias de vida ao considerar que estas poderão ter outros autores, nomeadamente os editores das obras, que tomam decisões importantes em função do público que as vai consumir. Nas histórias de vida corroboradas pela ciência esta última autoria não deverá ocorrer, ficando apenas aqui registada a multiplicidade de autores de uma simples história pessoal.

Mesmo nas autobiografias há dois sujeitos que, em rigor, não são idênticos. O que vê, vê-se num outro momento ou condição, não sendo entidades totalmente coincidentes. Fernando Pessoa(24), de forma sublime, já ilustrou esta duplicidade do ser, para o autor uma triplicidade de eus no eu. ${ }^{1}$ Paul Ricoeur(31) é assertivo quando defende que o conhecimento de si próprio é uma interpretação, fazendo da história de vida uma história fictícia, misturando-se história e ficção. A fenomenologia torna-se evidente nestas histórias e a hermenêutica surge como uma ferramenta indispensável para se compreender, com profundidade, uma história de vida contada pelo próprio ou através de uma terceira pessoa.

Ainda a este respeito é justo recordar Santo Agostinho(34), para quem Mihi quaestio factus sum (Confissōes. Livro 10: p. 33) [numa tradução livre: "eu sou feito para me procurar" ou, na tradução da edição da Martin Claret, "eis que me tornei um problema para mim mesmo"]. Note-se que este extraordinário homem da Igreja utiliza nesta expressão a primeira pessoa para designar o sujeito e o objecto. Santo Agostinho não perguntava pelo homem como uma coisa entre outras, mas por si mesmo. Como refere Julián Marías(18: p.14), “eu, como tal, eu mesmo, sou problemático".

Lembrava Jean Lacroix ${ }^{\text {(in 29) }}{ }^{2}$ que a pessoa é impossível de objectivar [de ser objecto], não se podendo fazer um inventário dela porque há sempre algo mais do que o dado, e só uma busca contínua poderá satisfazer a consistência necessária para o seu conhecimento. Diz ainda Lacroix que, para o homem, existir significa coexistir com os demais e com as coisas, 
compreendê-los compreendendo-se, compreender-se compreendê-los. A pessoa não sai do tempo. É presença no presente, condensando o passado e o futuro na sua existência, pelo que uma história de vida acaba por ser uma história da sua existência: da sua existência passada mas presenciada no agora; da sua existência futura porque se vive em busca de algo superior (transcendência?), sendo o plasmar da sua vida através de uma história um passo mais para se alcançar o altar do não esquecimento.

Esta visão proporcionada pela escola personalista remeteu-nos para Santo Agostinho (em especial as Confissões, Livro XI e para as suas conclusões, capítulo XX). Para este autor todo o tempo é presente: pela memória tornamos presente o passado; pela atenção o presente torna-se presente; e a esperança traz o futuro para o presente(34. Ver também 33). Não estaria Benedetto Croce a pensar neste santo da Igreja quando defendeu a posição, depois tornada clássica, que toda a história é história contemporânea? (in 11). Nas histórias de vida podemos entrever estas três dimensões do tempo presente, todas elas centradas no agora do duplo sujeito já mencionado. A vida no agora é, então, expressão dos três tempos avocados por Santo Agostinho. Não há somente um passado que condiciona o presente, mas uma representação do antes e do depois realizada no agora e assegurada pela duplicidade do(s) autor(es). No quotidiano do comum das pessoas, o futuro intervém seriamente no tempo presente, bastando para isso lembrar alguns aspectos triviais como os planos de reforma, os investimentos a longo prazo, os projectos de vida para nós próprios ou para os nossos descendentes (26). Por seu turno, muitas das actuais preocupações ecológicas, que condicionam decisões e práticas de diversos estados, centram-se no futuro, por vezes distante e nebuloso tendo em conta o breve tempo médio de vida das pessoas. A questão ecológica obrigou o homem a pensar o tempo através de um novo padrão: o do futuro longínquo. Martin Rees(30), astrofísico de formação, lembra que os horizontes temporais do homem eram muitos restritos e que os novos centros de interesse - alterações climáticas, lixos radioactivos, etc. - fizeram com que o ser humano despertasse para a realidade futura, naquilo que pode ser reduzido à trivial expressão o futuro no presente.
A antropologia há muito que lida com conceitos diferenciados de tempo. O eterno retorno que aparece amiúde em Nietzsche, Mircea Eliade e, entre nós, em Raul Proença, é uma modalidade de tempo que não se resigna à linearidade com que normalmente nos é apresentado. Constitui-se numa visão diferente que recusa uma cognição única do tempo, abrindo novas e amplas possibilidades interpretativas do fenómeno da temporalidade, sendo curioso verificar que todo mundo o mede com precisão mas ninguém o define em toda a sua extensão.

Não cabe neste breve ensaio problematizar o tempo. Para tal, teríamos que caminhar por vias que mal conhecemos, recorrer a autores de áreas científicas estranhas ao nosso quotidiano (Stephen Hawking), e enveredar por temas complexos como a relação existente entre vida e morte - uma relação temporal -, passando por três autores fundamentais para a sua discussão: Heidegger, que o situa na esfera da ontologia, Husserl, na fenomenologia, e Reichenbach, que o analisa na perspectiva da física relativista, pelo que o melhor é regressar à nossa simples reflexão. Voltemos, então, à questão da subjectividade das histórias de vida, deixando para trás esta imensa discussão sobre o tempo que permite pensar, face às conclusões extraídas pelos diferentes autores, que estamos perante uma pluralidade de objectos, tal a variedade de hipóteses, teorias e métodos existentes a esse respeito.

Não somos originais na percepção que temos da dupla subjectividade das histórias de vida. Muitos outros autores, embora por razões diferentes, já aludiram a esta subjectividade inerente às histórias de vida. Françoise Digneffe identifica as principais opções teóricas que se encontram na base da abordagem biográfica, em que o método biográfico permite: "sair da oposição entre indivíduo e sociedade" (8: p.206); "captar as relações dialécticas ou de circularidade entre o ponto de vista subjectivo do homem e a sua inscrição na objectividade de uma história" (8: p.207); "captar as «subjectividades», compreender de que modo a conduta é continuamente remodelada, de modo a ter em conta as expectativas dos outros"(8: p.208); "captar o que escapa às estatísticas, às regularidades objectivas dominantes, aos determinismos macrossociológicos" (8: p.209); e "reconhecer um valor sociológico no saber individual”(8: p.210). 
As histórias de vida possibilitam uma miríade de objectivos diferenciados, ultrapassando em muito a simples genealogia comportamental ou, por analogia semântica, pensamental ${ }^{2}$ de determinada pessoa. Faz todo o sentido retomar a concepção personalista que Emmanuel Mounier(in 29) desenvolveu na década de 30 do passado século. O mundo vivia as consequências da convulsão económica iniciada pela crise de 1929. As grandes causas da crise, embora económica, foram de natureza moral. Algo de análogo se pode estar a passar neste momento, pelo que recentrar a pessoa na reflexão das ciências do desporto, mais do que uma acidental possibilidade, constituise numa exigência ética.

Para ilustrar esta nossa posição recorremos novamente a Giovanni Pico della Mirandola(19: p.53): "Li nos escritos dos árabes, venerandos Padres, que, interrogado Abdala Sarraceno sobre qual fosse a seus olhos o espectáculo mais maravilhoso neste cenário do mundo, tinha respondido que nada via de mais admirável do que o homem. Com esta sentença concorda aquela famosa de Hermes: «Grande milagre, ó Asclépio, é o homem»".

É curioso saber que séculos antes, por meados do século IV a.C., Sófocles( ${ }^{(37)}$ dizia, através do Coro do drama Antígona, que "há coisas prodigiosas, mas nenhuma como o homem!".

Também para nós, passados tantos séculos, não há no desporto nada mais admirável do que o homem, neste caso o homem em determinada acção. Não numa acção qualquer, mesmo que implique movimento, mas numa actividade configurada em torno dos grandes valores éticos do desporto, que podem ser encontrados na trilogia olímpica, citius - altius fortius, que nada mais é do que um convite para que o homem se transcenda, aspiração essa, futura, que se desenvolve em todo o momento de vida.

Então, o nosso caminho, isto é o nosso itinerário, é em busca da transcendência, pelo que uma história de vida não pode situar-se simplesmente no antes de agora mas também projectar o futuro no agora.

Segundo Pomian(26), Kant já tinha entrevisto a relação entre o presente e o futuro, difundindo a ideia que como "seres pensantes, estamos orientados para o futuro". A experiência temporal não é apenas um registo nem está inteiramente subordinado ao passado, estando também voltada para o devir.
Esta visão projectiva do ser humano repercute-se seriamente numa concepção de história de vida, com manifestas implicações metodológicas, fazendo com que esta se volte também para as condicionantes que o futuro coloca ao presente, não se ficando pela linearidade temporal diacrónica - do passado para o presente - imposta por uma qualquer lógica mecanicista. Aceitamos que não é fácil intentar um discurso prospectivo quando a sociedade parece ser uma concatenação de momentos, visando a eternização do instante (17: p.2001). A tendência seguida pelas histórias de vida normalmente realizadas no campo das ciências do desporto expressa esta visão momentânea da sociedade, onde o presente, ancorado em pouco passado e sem nenhum futuro, comanda a vida.

Será interessante e justo dar voz àqueles que a levantam em favor das histórias de vida dentro da visão usual. Vejamos alguns autores de relevo nesta área. Para Poirier et al (25: p.xi) as histórias de vida são, actualmente, "utilizadas com frequência em antropologia, em sociologia, em psicologia e em história", devido à "crescente importância atribuída à utilização da memória oral e dos documentos pessoais na investigação em ciências sociais".

Pierre Bourdieu(4: p.53), um dos mais importantes nomes do mundo da sociologia, diz-nos que "falar de história de vida" é pressupor "que a vida é uma história e que uma vida é inseparavelmente o conjunto dos acontecimentos de uma existência individual concebida como uma história e a narrativa dessa história". Recorrendo às histórias de vida, solicitaremos às pessoas que, novamente na concepção de Poirier et al (25: p.92), contem ou descrevam a sua história pessoal, podendo "constituir um instrumento essencial de pesquisa em ciências humanas".

Do mundo da investigação no desporto impõe-se ouvir Antonino Pereira(23: p.163), que assevera que o objectivo do método biográfico - com vastos pontos de contacto com as histórias de vida - é de uma "dialéctica do social, ou seja, aprender o indivíduo como produto das relações sociais", o que vai de encontro a Adolfo Casal(5: p.109) para quem cada pessoa "nasce num mundo sociocultural historicamente pré-organizado, contendo semelhanças e diferenças". Acrescenta ainda o autor que estes mundos socioculturais se organizam em diversos grupos, segundo vários aspectos, onde cada indivíduo ocupa um espaço próprio. 
Por estes extractos de textos de autores de diversas proveniências da ciência, verifica-se que uma história de vida se referencia ao passado, à história recuperada pela memória - qual arqueologia -, ocupando a oralidade uma importância primordial para a sua efectivação, fruto de uma amálgama de relações difusas com o exterior, acima de tudo centrada no sujeito a quem se dá a palavra, esquecendo-se que o outro sujeito, o que estabelece a história, também está ligado às condições e aos acontecimentos do seu tempo. Separar os dois sujeitos é um erro que importa não cometer, sendo mais uma dificuldade para que possamos conhecer com razoável neutralidade o sujeito narrado. Defendemos que, de certa forma, conhecer é interagir, mas há sempre a real possibilidade de sairmos por completo do campo de existência do narrado, contaminando-o com as nossas perspectivas, conceitos ou valores. Recorrendo outra vez a Tierney ${ }^{(39)}$, verificamos que há consciência por parte dos teóricos das histórias de vida que a memória poderá ser influenciada pelo pesquisador, pelo tempo presente e mesmo por um processo de identidade do grupo onde se está inserido.

Assim sendo, uma história de vida resulta da conexão entre dois sujeitos, pelo que deverá ser lida ou compreendida à luz deste pressuposto. Mais do que uma metodologia, história de vida é já um acto contemplativo: do passado contemplado no presente e do futuro projectado pelo e no agora. Não pode ser apenas a simples narração pela memória do passado. Evitar um excesso de passado deverá ser uma exigência em nome de uma visão global do ser humano. A percepção que a memória - elemento fundamental para o estabelecimento de uma história de vida - não se restringe ao passado já vem de muito longe. Boncompagno da Signa, em 1235 [Rhetorica novissi$\mathrm{ma}$, sobre o que é a memória, apontava que a memória é um glorioso e admirável dom da natureza, através da qual reevocamos as coisas passadas, abraçamos as presentes e contemplamos as futuras, graças à sua semelhança com as passadas(in 15). Torna-se óbvio que é necessário um método para estabelecer a história de vida de alguém, caso contrário poder-se-á ficar perante uma visão impressionista e não diante de um estudo de feição científica. Porém, as histórias de vida não são propriamente uma metodologia, mas o resultado da correcta utili- zação de instrumentos ou ferramentas metodológicas - em especial de entrevistas, análise documental, hermenêutica, etc. - que vão permitir atingir os objectivos desejados.

Numa concepção de história linear, onde o presente é uma simples consequência do passado, à oralidade podemos adicionar outras fontes de informação, tais como documentos escritos ou afins. Na óptica que o presente, mais do que um tempo que seguiu pegadas do passado se assume como a tentativa de concretização do futuro, as dificuldades metodológicas são um pouco maiores, sendo de todo necessário entrar por caminhos próximos da hermenêutica e como tal menos descritivos e mais contemplativos - a aristotélica theoría. Aos habituais métodos etnográficos juntam-se outros de cariz filosófico. Cremos que só desta união de tempos e de instrumentos se poderá perceber a história de uma vida humana.

É nossa convicção, assumindo o valor que uma convicção tem na ciência, que tão importante como a história cronológica é uma história temática. Por este meio é possível sintetizar os diferentes componentes do tempo.

\section{HISTÓRIA DE VIDA, HISTÓRIAS DE VIDA OU HISTÓRIAS DE VIDAS?}

Da mesma forma que o matemático gosta do rigor com que os números são expostos e analisados, também as pessoas que transmitem as suas ideias através de palavras gostam que estas exprimam aquilo que se pensa, e que sejam devidamente compreendidas e não deturpadas no ou nos sentidos atribuídos pelo autor. Contudo, no momento em que a palavra é dita, fica dita. Sai do nosso campo de intervenção passando a fazer parte de um grupo maior, abandonando o nosso domínio único, ingressando num âmbito mais vasto. Acrescentamos ainda que uma palavra pronunciada (escrita ou falada) tem sentido porque é captada por alguém, ficando sujeita aos valores de quem a escuta. Sabemos que há mais ideias do que palavras, pelo que uma palavra poderá possuir vários significados, mas não um número infinito de sentidos( ${ }^{(9)}$. Esta multiplicidade de significados torna-se ainda mais evidente quando nos lembramos que existe um emissor, que emitiu uma palavra com determinada intenção, e um receptor, que a pode escutar e processá-la a partir de uma outra interpretação. $\mathrm{O}$ acto de escutar, diferente 
de ouvir - este mais relacionado a processos fisiológicos -, encontra-se intimamente ligado a uma hermenêutica(3), sendo um exercício de inteligência, ou seja, de selecção.

É por causa desta e de outras razões mais ou menos subtis que faz sentido interrogarmo-nos sobre a melhor designação para enunciar aquilo que queremos com a expressão história de vida.

Aparentemente é uma narrativa sobre factos do nosso passado. Mas também pode ser entendida como um enredo ou uma récita, isto é, uma representação desse mesmo passado. Ora, na antropologia simbólica representação significa, grosso modo, tornar presente. Neste caso tornamos presente o passado, pelo que não será descabido afirmar que sobre o mesmo trajecto se poderão constituir, ou escrever, várias histórias. Em cada momento o passado pode ser visto de forma diferenciada, com maior ou menor valor explicativo para a justificação de determinado comportamento ou forma de pensar, pelo que a concepção linear e causal dos acontecimentos ocorridos no tempo pode não ser tão evidente como isso. Não negamos que existam fenómenos de permanência na pessoa independentemente do tempo em que são recordados, como temos de considerar a erosão/evolução/diferenciação que o tempo provoca no ser humano, perceptível na frase comum: "eu era assim mas agora modifiquei-me”. A expressão eis-me assim é temporal, referente ao momento, e topográfico, referente ao lugar. Para mais, cada época e cada cultura privilegiam determinados valores, estruturandose em função desse eixo, pelo que a recordação de factos antigos poderá estar também condicionada pelo ambiente axiológico vigente.

É evidente que não rejeitamos a posição de Antonino Pereira(23: p.169) quando defende que se "queremos compreender a razão pela qual os profissionais de Educação Física e desporto actuam (...) precisamos de saber mais acerca da sua vida", mas poderemos sempre questionar se aquela história de vida não deverá estar devidamente referenciada ao momento do seu estabelecimento. Num outro momento, com um outro ânimo e com outro investigador, a história poderia ser manifestamente diferente. Nas nossas experiências de terreno já verificamos esta possibilidade, onde o pensamento actual contagia a memória sobre o passado.
Uma história é elaborada num tempo, num dado ambiente cultural. Repare-se, por exemplo, no que diz Antonio Chizzotti(6: p.226) sobre a etnografia. Para este autor etnografia pode "ser encontrada nos relatórios coloniais e nas descrições de outros povos, relatadas pelos conquistadores de suas novas possessões ou de indígenas". As histórias das relações entre europeus e africanos contadas há um século e agora são substancialmente diversas. São outras histórias. A história pessoal não está imune aos contágios do tempo, que no fim de contas se traduz numa contaminação moral, pelo que uma vida, que é algo que flúi, dificilmente poderá ser agarrada por uma só história. Uma vida comporta muitas histórias ["all human beings have a story, even many stories"] (2: p.22), tantas as pessoas que as elaboram e quantas vezes é elaborada, mesmo que pelo próprio. Assim, mais correcto do que afirmar a feitura da história de vida de alguém, será assumir que se escreveu uma história de vida, na convicção que a efemeridade da ciência também se faz sentir nestas récitas. É possível que o plebeísmo estória possa proporcionar-nos algum conforto. A soma dessas estórias, algumas das quais ilógicas, desconexas e inverosímeis, poderá dar-nos a (uma) história de uma existência.

De certa forma Ricardo Vieira(42: p.50) garante alguma consistência às nossas posições quando afirma que nas ciências humanas e sociais se sabe que "o objecto, as pessoas e as suas relações, têm significados próprios", em que "os actores dão sentido e significado às suas práticas", sendo que o objectivo último do método etnográfico, onde se podem incluir as histórias de vida, é "justamente captar esses significados".

A dupla subjectividade faz com que caminhemos para a pluralidade do conceito de história quando referenciada à vida humana.

Podemos ir um pouco mais além nesta reflexão quase epistemológica - sobre as histórias de vida, talvez complicando (não complexificando) a temática, mas com o objectivo de tentar clarificá-la.

O senso comum é uma importante fonte de conhecimento. Boaventura Sousa Santos(38) não teve receio de apontar a segunda ruptura epistemológica como sendo a necessidade de romper com a primeira ruptura, que postulava a ruptura com o senso comum. Este conhecimento, quando devidamente comparti- 
mentado, traduz-se numa importante fonte de reflexão que interessa analisar.

Em algumas histórias de vida que temos vindo a realizar é costume ouvir-se dizer que "sobre a minha vida privada não converso", que "só falo sobre a minha vida desportiva" e que "sobre a minha vida empresarial não me pronuncio". São três exemplos, reais, que ilustram aquilo que a sociologia há muito sabe: temos um vasto número de papéis sociais, pelo que é legítimo pensar, nem que seja apenas para se colocar uma hipótese, que na nossa vida coexistem várias vidas. Nestes exemplos presenciámos três vidas, a saber: desportiva - de que fala -, empresarial - a que não se quer referir - e pessoal - da qual nem admite indagações. Na realidade estamos perante três papéis sociais desempenhados por uma pessoa a que ela, tal como é percebido pelo senso comum, atribui o estatuto de vidas. Mais do que uma vida temos vidas! De algumas podemos conversar, enquanto que para outras há uma interdição expressa. De que é que estamos a falar para que o outro estabeleça a nossa história?

Parece-nos que esta discussão nos leva para um poço sem fundo, tal a quantidade de dúvidas que são levantadas a cada momento. Provavelmente a solução estaria no uso da palavra e de conceitos matemáticos. Por tudo o que já foi exposto talvez a designação mais correcta fosse (histórias de vidas) ${ }^{2}$ [histórias de vida ao quadrado] isto é, uma designação que evidenciasse que estamos perante dois sujeitos, com as suas histórias e com as suas diferentes vidas, pelo que o resultado final - a história de vida - é uma confluência de múltiplas condições.

\section{CONTRIBUTO PARA UM NOVO ITINERÁRIO DAS HISTÓRIAS DE VIDA}

É fácil cair na tentação de atribuir a um determinado facto singular ocorrido no passado a capacidade de explicar algum comportamento diferenciado de excelência na actualidade, havendo sempre a certeza da causalidade de... casualidades. Num sistema fechado, onde todos os passos são devidamente controlados, é possível procurar, desencadear e estabelecer tais causalidades geradoras de previsibilidades, mas a vida humana, para mais quando contada a posterio$r i$, assume-se como um sistema demasiado aberto para que se infiram tais certezas.
Passados mais de 150 anos sobre o nascimento de Sigmund Freud, continuamos reféns de um pensamento sobre o tempo, cuja linearidade é indiscutível. Continuamos a pensar na exclusividade do passado para a justificação da actualidade, esquecendo que o tempo - conjugação do passado, do presente e do futuro - é um todo indissociável. Admitimos que racionalmente é mais confortável ver no passado a exclusiva responsabilidade dos comportamentos ou pensamentos actuais. O carácter científico e racional da linearidade temporal fica mais patente através desta visão do que através de um método que perscrute o futuro com a mesma intensidade e com igual valor elucidativo para o entendimento do presente. Leonardo Coimbra já em 1913 tinha manifestado algum desconforto com a ideia da linearidade das histórias de vida, nomeadamente quando evidencia que "se a vida é uma história, o que se diz da história de vida, verdadeiro é da própria vida, sempre e agora, no fluxo e no limite, que lhe respeite a estrutura" (in 22: p.283). Continua o autor, devidamente comentado pelo Professor Manuel Patrício, dizendo que "não têm razão os inferiozadores, que querem inutilmente achar uma continuidade, que apresente um momento como simples resultado dos antecedentes" (idem, ibidem).

A concepção linear e causal da vida poderá ter raízes numa certa visão mecanicista do mundo.

Regressando a Antero de Quental(28: p.143) vemos que vivemos no "mundo da mecânica. É o mundo da necessidade. Reina ali (...) o princípio da causalidade mecânica (...) Uma acção é provocada por outra e a sua intensidade é medida pela intensidade da que a provocou", não existindo a possibilidade da espontaneidade.

Relativamente à nossa proposta - ou hipótese de proposta - poder-se-á objectar dizendo que é possível encontrar no passado os fundamentos de um nosso desejo futuro, mas tal também poderá acontecer com as genealogias da vida, ou seja, ter que encontrar no passado a causa de um desejo presente. Em ambos poderá haver a transferência de um desejo actual, seja para o futuro, seja para o tempo pretérito. Curiosamente, Vitorino Nemésio(20: p.154), esse enorme vulto da cultura portuguesa, escrevia "não que uma árvore genealógica, mesmo bem historiada, explique muito mais, sobre as motivações da condu- 
ta de um homem, do que um encadeamento biomolecular de cromossomas, portadores de genes a que um bom microscópio electrónico acuse os mensageiros do código: não!".

Anaximandro, num texto que tem sido alvo de muitas discussões, defendeu a tese que "onde estiver a origem do que é aí também deve estar o seu fim"(in 14: p.200). Cada um é livre de interpretar este fragmento da melhor maneira possível. Nós, neste enunciado com mais de 2.500 anos, percebemos o tempo. É nele que reside o princípio e o fim.

A história de vida deve ser entendida como um itinerário para a concretização de um projecto de vida. Para tal há um objectivo a almejar, isto é, há um desígnio a alcançar. Então, o itinerário não poderá ser apenas uma linha do passado para o presente, diacrónica, nem somente a percepção dessa linha pelo presente, perspectiva sincrónica, mas também o percurso do futuro para o presente e, porque não, para o passado.

Qual gráfico, é possível documentar a nossa proposta para um possível itinerário de uma história de vida, aqui entendida enquanto conjunto de procedimentos do campo das ciências humanas:


Esquecer o passado para o estabelecimento de uma história de vida é um erro tão crasso como omitir o futuro, nem que seja para conhecer os sonhos que se querem alcançar, quando o desejo declarado é o de compreender o presente de alguém.

Desta forma, o possível triângulo memória, identidade e narração, que por vezes é apresentado para dar corpo a uma história de vida(7), terá que evoluir para uma outra qualquer figura geométrica que convoque mais um vértice, o da esperança. É também por ela que o nosso quotidiano se estabelece. Em boa verdade dever-se-á manter o triângulo, sendo os vértices os valores invocados por Santo Agostinho para cada uma das dimensões do tempo: a memória, a atenção e a esperança, estando a narrativa inscrita no centro desse triângulo. Passado e futuro, ou se quisermos memória e esperança (e por que não escatologia, doutrina dos fins últimos?) convergem no tempo actual, renunciando-se à temporalidade simplesmente linear, abrindo-se a possibilidade que outras formas de compreensão do tempo emirjam. Para Raul Proença(27: p.58) "toda a vida humana digna desse nome gravita entre uma alta aspiração e uma larga esperança". Este autor, ao analisar o livro de Nietzsche Assim falava Zaratustra, lembra a expressão do "eterno fugitivo do presente"(27: p.66), onde se cruzam dois caminhos: do passado e do futuro. Teixeira de Pascoaes(21: p.238), o poeta que cantou a alma lusitana, já dizia que "tocamos a lembrança e a esperança". Era por esta visão que percebia o milagre da saudade. Sublime, cantava ainda:

"Acreditai até no que não há.

Que esse impossível, esse nada existirá".

Vejamos o caso do desporto. Quantos atletas não condicionam o seu dia-a-dia pelo desejo de participar, daí a alguns anos, numa competição olímpica? Os depoimentos de atletas lidos na imprensa ou ouvidos nas rádios e televisões são elucidativos, levando-nos para uma resposta positiva à questão retórica colocada anteriormente. O futuro, o desejo de um êxito de natureza múltipla - reflecte-se na vida presente dos atletas, contribuindo decisivamente para a adopção de comportamentos que a vida passada poderá não ter capacidade per se de os legitimar.

Nunca é de mais recordar as palavras de Mário Moniz Pereira relativamente ao seu sonho de ver a bandeira portuguesa no mastro maior de um estádio olímpico. Foi essa esperança que moldou o quotidiano do treinador luso com maior palmarés desportivo. Não negamos a importância do seu passado, resgatado pela memória(ver 23: p.2001) para a compreensão do "seu presente", mas o seu desejo futuro não é um elemento despiciendo para se atingir o entendimento sobre a sua conduta. O seu passado e a sua aspiração futura corporizaram o presente.

Romano Guardini(13), na sua magistral Ética, ao falar sobre o homem, diz que é necessária uma perspectiva teleológica para distinguir a verdade a que ele chama de interior da falsidade. Convém reflectir, nas histórias de vida, tanto nos fundamentos como nas finalidades da vida humana, podendo o desporto, dada a sua natureza, seus princípios basilares e seus objectivos centrais, ser um óptimo cadinho para efectivar esta experiência sobre as histórias de vida. É esta a nossa concepção de história de vida e que queremos validar em estudos futuros. 


\section{CONSIDERAÇÕES FINAIS}

1. Não temos pretensões de anunciar um novo paradigma nem de acentuar uma clara ruptura com práticas comuns nas histórias de vida amplamente descritas na bibliografia das ciências sociais e humanas. A nossa aspiração é bastante mais modesta, a de encetar uma "conversa" com a teoria hegemónica no sentido de conferir alguma validade ao nosso pensamento que se pode resumir a uma pequena expressão: evitar o excesso de passado nas histórias de vida. O contributo que quisemos dar à discussão de cariz epistemológico relativamente às histórias de vida foi o de apresentar uma visão de vida não regida apenas pela velha concepção cronológica de acontecimentos. As ciências humanas, sem serem dependentes da física moderna, não poderão esquecer as modificações drásticas que esta ciência introduziu na física "tradicional" de Newton. O tempo, no fim de contas onde está inserida a nossa história pessoal, é uma entidade complexa que reclama essa complexidade para ser compreendido. Ampliar um conceito não significa renunciá-lo.

2. Assim, como complemento às tradicionais visões diacrónica e sincrónica das histórias de vida, admitir a possibilidade dos desejos futuros - sonhos e utopias mas não só - possam também ter algum valor explicativo sobre o presente, conferindo à história de vida uma outra dimensão mais consentânea com a ideia da existência como um todo, domesticando desta forma as lembranças passadas e as aspirações futuras.

3. Podemos ainda concluir que o desporto é um excelente meio para se compreender a importância que o futuro tem nas nossas vidas, não apenas por ser uma actividade que permite o salto transcendental, que projecta o homem para a eternidade, como também pelo facto do "treino de hoje" estar objectivado por um desempenho futuro.

4. Assumir a intersubjectividade decorrente dos vários sujeitos intervenientes numa dada história de vida, e aos diferentes tempos convocados, pelo que as leituras dessas histórias pressupõem uma dupla, mesmo múltipla, hermenêutica.

5. Uma história de vida, tenha a designação que tiver, deverá ser um texto redigido sem o "ponto final". Deverá assumir-se como um convite para a abertura de um diálogo entre o narrado, o narrador e o leitor, onde este último reescreve aquilo que foi plasmado no papel por outrem. Deverá ser também um convite à metalinguagem, possibilitando que cada facto, cada opção, cada comportamento, possam ter sempre novas interpretações desde que não desvirtuem o universo cultural da pessoa narrada.

\section{AGRADECIMENTOS}

Os autores agradecem os importantes contributos sugeridos pelo Doutores Manuel Ferreira Patrício, Antonino Pereira, Jayme Valente, Ana Luísa Pereira e pelos Mestres José Mário Cachada, Humberto Rêdes, Fátima Santos. Um agradecimento especial à Dra. Daniela Cachada. Paula Portugal é bolseira da Fundação para a Ciência e a Tecnologia (SFRH/BD/43477/2008).

\section{NOTAS}

${ }^{1}$ Referimo-nos ao seguinte poema: Brincava a criança / Com um carro de bois. / Sentiu-se brincando / E disse, eu sou dois!

Há um a brincar / E há outro a saber, / Um vê-me a brincar / E outro vê-me a ver.

${ }^{2}$ Devemos esta palavra ao Doutor Manuel Ferreira Patrício, ouvida durante uma conversa informal.

\section{CORRESPONDÊNCIA}

\section{Rui Proença Garcia}

Faculdade de Desporto

Rua Dr. Plácido da Costa, 91

4200-450 Porto

Portugal

E-mail: rgarcia@fade.up.pt 


\section{BIBLIOGRAFIA}

1. Aristóteles. Da alma (de anima). Lisboa: Edições 70 (edição de 2001)

2. Atkinson, R (1998). The life story interview. Thousand Oaks, California: Sage Publication

3. Barthes R, Havas R (1987). Escuta. In Enciclopédia Einaudi. Lisboa: Imprensa Nacional - Casa da Moeda, vol. 11, 137145

4. Bourdieu P (2001). Razões práticas. Sobre a teoria da acção. Oeiras: Celta Editora ( $2^{a}$ edição)

5. Casal A (1996). Para uma epistemologia do discurso e da prática antropológica. Lisboa: Cosmos

6. Chizzotti A (2003). A pesquisa qualitativa em ciências humanas e sociais. Rev Port Educação, 16 (02): 221-236

7. Conde I (1994). Falar da vida (II). Sociologia - problemas e práticas, 16: 41-74

8. Digneffe F (2005). Do individual ao social: a abordagem biográfica. In Luc Albarello, Françoise Digneffe, Jean-Pierre Hiernaux, Christian Maroy, Danielle Ruquoy, Pierre de Saint-Georges, Práticas e métodos de investigação em ciências sociais. Lisboa: Editora Gradiva, 203-245

9. Eco U (1992). Os limites da interpretação. Lisboa: Difel

10. Entralgo PL (2003). Corpo e alma. Coimbra: Almedina

11. Gardiner P (1984). Teorias da história. Lisboa: Fundação Calouste Gulbenkian

12. Giddens A (1996). Novas regras do método sociológico. Lisboa: Gradiva

13. Guardini R (1999). Ética. Lecciones en la Universidad de Múnich. Madrid: Biblioteca de Autores Cristianos

14. Jaeger W (2003). Paidéia. A formação do homem grego. São Paulo: Martins Fontes

15. Le Goff J (1997). Memória. In Enciclopédia Einaudi. Lisboa: Imprensa Nacional - Casa da Moeda, vol. 1, 11-50

16. Le Goff J (1997). História. In Enciclopédia Einaudi. Lisboa: Imprensa Nacional - Casa da Moeda, vol. 1, 158-259

17. Maffesolli M (2001). O eterno instante. O retorno do trágico nas sociedades pós-modernas. Lisboa: Instituto Piaget.

18. Marías J (1996). El tema del hombre. Madrid: Editorial Espasa Calpe

19. Mirandolla, GP. Discurso sobre a dignidade humana (edição bilingue). Lisboa: Edições 70. Tradução e apresentação de Maria de Lourdes Sirgado Ganho (edição de 2006. $1^{\mathrm{a}}$ edição de 1486)

20. Nemésio V (2003). Obras completas. Vultos e perfis I (vol. XXV) Lisboa: Imprensa Nacional - Casa da Moeda

21. Pascoaes T (1988). A saudade e o saudosismo. Lisboa: Assírio \& Alvim

22. Patrício MF (1992). A pedagogia de Leonardo Coimbra. Porto: Porto Editora

23. Pereira A (2001). A excelência profissional em Educação Física e desporto: perfil a partir de 7 histórias de vida. Dissertação de Doutoramento. Porto: Faculdade de Desporto da Universidade do Porto
24. Pessoa F (2006). Poesias do eu. Lisboa: Círculo de Leitores (edição de Richard Zenith. Poema escrito em 5.12.1927)

25. Poirer J, Clapier-Valladon S, Raybaut P (1999). Histórias de vida. Oeiras: Celta Editora ( $2^{\mathrm{a}}$ edição)

26. Pomian K (1993). Tempo/temporalidade. In Enciclopédia Einaudi. Lisboa: Imprensa Nacional - Casa da Moeda, vol. 29, 11-91

27. Proença R (1987). O eterno retorno. Lisboa: Biblioteca Nacional

28. Quental A (1990). Obras Completas - Filosofia. Lisboa: Editorial Comunicação e Universidade dos Açores

29. Reale G, Antiseri D (1991). Historia del pensamiento filosófico y cientifico. Barcelona: Editorial Herder (3 volumes)

30. Rees M (2006). O princípio e o fim do tempo. In Rui Fausto e Rita Marnoto (coordenadores) Tempo e ciência. Lisboa: Gradiva, 15-37

31. Ricoeur P (1988). L’identité narrative. Esprit, 7-8: 295-304 (tradução de Carlos João Correia, in Arquipélago/Série Filosofia, no 7, Revista da Universidade dos Açores, 177 194)

32. Rubio K (2001). O atleta e o mito do herói. O imaginário esportivo contemporâneo. São Paulo: Casa do Psicólogo

33. Santo Agostinho. A cidade de Deus. Lisboa: Fundação Calouste Gulbenkian (2a edição, 1996)

34. Santo Agostinho. Confissões. São Paulo: Martin Claret (edição de 2002)

35. Santos F (2005). A atitude dos pais perante o (não) desenvolvimento motor de sua Filha. História de vida de uma criança com Mucolipidose II. Dissertação de Mestrado. Porto: Faculdade de Desporto da Universidade do Porto

36. Savater F (2004). A coragem de escolher. Lisboa: Dom Quixote

37. Sófocles. Antígona - Ájax - Rei Édipo. Lisboa: Editorial Verbo (edição sem data).

38. Sousa Santos B (2001). Um discurso sobre as ciências. Porto: Edições Afrontamento (12 a edição)

39. Tierney W (2000). Undaunted courage: Life history and the postmodern challenge. In Norman Denzin \& Yvonna Lincoln (Editors) Handbook of Qualitative Research. Thousand Oaks, California: Sage Publication, 537-553

40. Valente J (2006). Mário Jorge Lobo Zagallo: entre o sagrado e o profano - uma história de vida. Dissertação de Doutoramento. Porto: Faculdade de Desporto da Universidade do Porto

41. Vaz H (1992). Antropologia filosófica - II. São Paulo: Edições Loyola

42. Vieira R (1998). Vidas revividas: etnografia, biografias e a descoberta de novos sentidos. In Telmo H. Caria (org.) Experiência etnográfica em ciências sociais. Porto: Edições Afrontamento, 77-95

43. Wittgenstein L (1996). Cultura e valor. Lisboa: Edições 70 